\title{
Subcapsular hemorrhage of the liver after laparoscopic cholecystectomy,
} a case report

\author{
Suwandhi Widjaja ${ }^{*}$, Sumanto Simon $^{\dagger}$, Aru Witjaksono Sudoyo $^{\dagger}$
}

\begin{abstract}
Abstrak
Seorang wanita berusia 44 tahun dengan diagnosis kolesistitis kronika dengan batukandung empedu telah dilakukan kolesitektomi laparoskopik. Setelah tindakan, penderita mengeluh nyeri pada perut kanan atas disertai penurunan hemoglobin. Pada pemeriksaan USG maupun CT-scan terlihat adanya perdarahan subkapsular hati pada lobus kanan dibawah diafragma. Pada laporan kasus ini dibahas mengenai etiologi komplikasi yang sangat jarang ini.
\end{abstract}

\begin{abstract}
A woman of 44 years old with diagnosis of chronic cholecystitis with gall stones had undergone laparoscopic cholecystectomy. After the procedure, she complained of dull pain in the right upper abdomen with the declining of hemoglobin level. The USG and CTscan examination showed hepatic subcapsular hemorrhage on the subphrenic right lobe. The causes of this very unsual complication was discussed in this report.
\end{abstract}

Keywords: laparoscopic cholecystectomy, liver nupture, complication

Laparoscopic cholecystectomy was first performed in France in 1987. ${ }^{1,2}$ This technique has gained remarkably rapid widespread use and acceptance all over the world, and become the standard for the treatment of acute as well as chronic cholecystitis. Retrospective comparative studies between laparoscopic cholecystectomy and open cholecystectomy showed that laparoscopic cholecystectomy resulted on shorter hospital stay, more rapid recovery, and minimal use of post operative analgesia than open cholecystectomy. 3,4

However, the laparoscopic cholecystectomy were comparable with open cholecystectomy in types and number of complications. ${ }^{5}$ Complications of this technique were problems related to distention of the peritoneal cavity, lack of depth perception afforded by video image and problems related to new instruments used in this technique. ${ }^{6}$ The most common complications of Iaparoscopic cholecystectomy were biliary duct injury such as stricture or bile leakage, vascular

\footnotetext{
${ }^{*}$ Research Laboratory for Viral Hepatitis Atma Jaya School of Medicine, Jakarta, Indonesia

${ }^{\dagger}$ Department of Internal Medicine, Faculty of Medicine, University of Indonesia, Jakarta, Indonesia
}

injury such as hemorrhage or arterio-biliary fistula, infection/abscess, superficial wound infection, and conversion to open cholecystectomy. These complications occurred in approximately $5.1 \%$ to $7 \%$ of the procedures depend on the centers. ${ }^{7,8,9}$

Although there were several reports of unusual complications of laparoscopic cholecystectomy reported by several investigators, such as right paranephric abscess, ${ }^{10}$ renal vein thrombosis, ${ }^{11}$ arterio-biliary fistula, ${ }^{12}$ pseudoaneurisms, ${ }^{13}$ splenic rupture, ${ }^{14}$ there was no any report concerned about the liver rupture as the complication of this procedure. In this report we present a case with subcapsular hemorrhage of the liver as an unusual complication of laporoscopic cholecystectomy.

\section{CASE REPORT}

A 45 years old woman with symptomatic chronic cholecystitis with gall stones was admitted to Medistra Hospital on November $16^{\text {th }} 1997$, for laparoscopic cholecytectomy. All her physical examination and laboratory findings were unremarkable. The hemoglobin level was $12.3 \mathrm{~g} \%$, wbc and thrombocyte were $7000 / \mu 1$ and $216000 / \mu 1$, respectively. The bleeding parameters consisted of prothrombine time, bleeding time and coagulation time were unremarkable. The 
liver function test such as serum albumin was $4.4 \mathrm{~g} / \mathrm{dl}$, globuline was $2.3 \mathrm{~g} / \mathrm{dl}$, direct and indirect bilirubin were $0.2 \mathrm{mg} / \mathrm{dl}$ and $0.1 \mathrm{mg} / \mathrm{dl}$ respectively, the transaminases were $12 \mathrm{U} / \mathrm{l}$ for AST and $16 \mathrm{U} / 1$ for ALT. The blood ureum was $28 \mathrm{mg} / \mathrm{dl}$.

Laparoscopic cholecystectomy was performed on the next day, in accordance to the standard procedure, uneventful course of the operation was notified.

After the procedure, the patient was complained of dull pain in the right upper abdomen. The physical examination showed no sign of acute abdomen or hipovolemic shock, however, the hemoglobin level progressively declined, from $12.3 \mathrm{~g} \%$ to $7.8 \mathrm{~g} \%$. Based on those findings, intra abdominal hemorrhage was suspected and USG was performed immediately. The USG showed multiple hypoechoic structures which ran rather horizontally among the fragmented liver tissue within subcapsular liver right lobe space, just beneath the diaphragm. These findings were compatible with the liver rupture with large hematoma. The CT-scan was performed and confirmed these findings Figure 1 [arrow]. These findings were different to the pre operative USG, in which the liver was entirely normal without any lesion at all. Since the patient's general condition was not deteriorated and the hemoglobin level was not further declining, the conservative treatment with blood transfusion was applied. The patients showed uneventful recovery and was discharge from the hospital on November $24^{\text {th }}$ 1997.

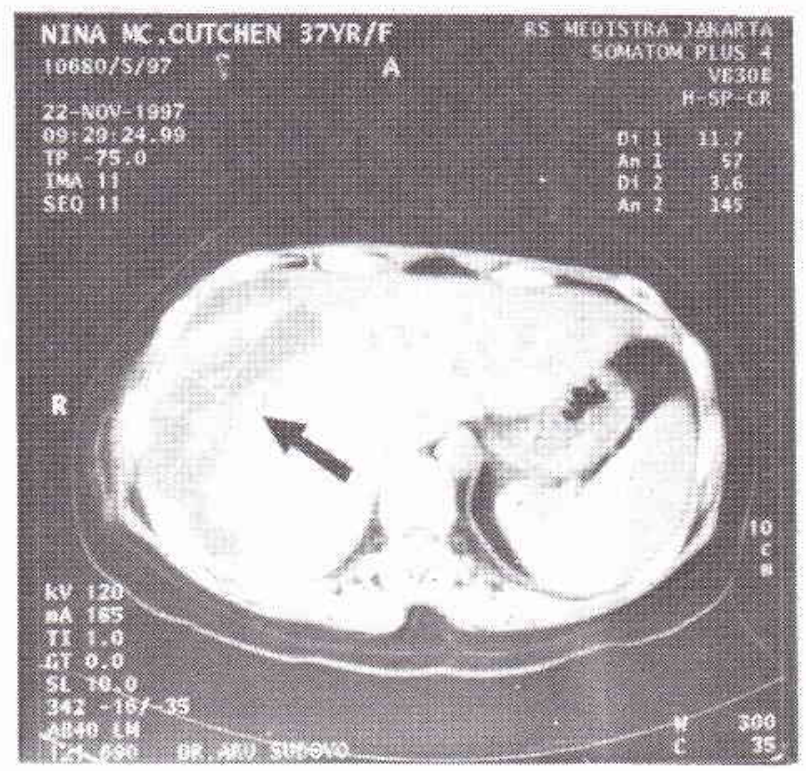

Figure 1. This CT-scan showed a large sub-capsular hematoma (arrow) on the subphrenic right lobe of the liver. The liver was torn horizontally rather vertically.

\section{DISCUSSION}

The complications of laparoscopic cholecystectomy are divided into several catagories. The most common complications are those related to the lack of depth perception afforded by video image and new instruments used in this technique. In this group, the most complications are vascular or biliary injury, which causes the such bleeding, stricture of biliary duct or biliary leakage. The other complications are related with the introduction of laparoscopic instrument through the abdominal wall, which injures the major blood vessels or the intestines. The problerns related to the distention of the peritoneal cavity are also an important factor to convert the laparoscopic approached to open cholecystectomy. This complications, such as adhesions due to prior operation or previous abdominal infection may cause the laparoscopic cholecystectomy became more delicate and increased the likelihood of convertion to open cholecystectomy. In this group of complications, the carbon dioxide pneumoperitoneum used during the laparoscopic cholecystectomy can cause adverse local and systemic effects, such as gas embolism, hypercapnia, acidosis, and arrhythmias. ${ }^{15,16,17}$

However, subcapsular hemorrhage of the liver after laparoscopic-cholecystectomy so far was never reported in the literatures, thus this is may be the first report in the journal. The exact cause of liver rupture in this case is not clearly defined because no laparotomy was performed. In this case, there is no history of abdominal operation, but she had obviously chronic recurrent inflamation of the gall bladder, which may induce the adhesion of the liver to the diaphragm or the abdominal wall.

As shown on the CT [figure 1], the liver was, torn horizontally rather vertically. This finding supports the suggestions that the rupture may be due to the disruption of the liver capsule by traction on liver adhesion to diaphragm by pneumoperitoneum or occured during the removal of the gall bladder. This suggestion may be comparable with the splenic rupture after laparoscopic cholecystectomy and during the explorative abdominal operation in which the splenic capsule was torn on its adhesion to surroundings. ${ }^{14}$ One other possibility is the hepatic rupture happened due to injury by the introduction of laparoscopic instrument during the procedure.

\section{REFERENCES}

1. Dubois F, Berthelot G, Levard H. Cholecystectomie par coelioscopie. Press Med 1989 ; 18: 980. 
2. Dubois F, Icard P, Berthelot G, et al. Coelioscopic cholecystectomy: preliminary report of 36 case. Ann Surg 1990; 211 $: 60$.

3. Stoker ME, Vose J, O'Mara P, et al. Laparoscopic cholecystectomy: a clinical and financial analysis of 280 operations. Arch Surg 1992; $127: 589$.

4. Glinatsis MT, Griffith JP, McMahon MJ. Open vs laparoscopic cholecystectomy: a retrospective comparative study. J Laparoendosc Surg 1992; $2: 81$.

5. Herrera MF, Chan C, Gonzalez-Ojeda A, Torres G, Mercado MA, de la Garza L, et al. Comparison of outcomes and complications for open and laparoscopic cholecystectomy in Mexico. J Laparoendosc Surg 1995 Oct; 5(5): 289 - 93.

6. Deyo GA. Complications of laparoscopic cholecystectomy. Surg Laparosc Endosc 1992 Mar; 2(1): 41 - 8.

7. The Southern Surgeons Club. A prospective analysis of 1518 laparoscopic cholecystectomies. New Eng J Med 1991; 324 $: 1073$.

8. Graber JN, Schultz LS, Pietrafitta JJ, Hickok DF. Complications of laparoscopic cholecystectomy: a prospective review of an initial 100 consecutive cases. Lasers Surg Med 1992; 12(1): $92-7$.

9. Wolfe BM, Gardiner BN, Leary BF, Frey CF. Endoscopic cholecystectomy. An analysis of complications. Arch Surg 1991 Oct; 126(10): 1192 - 6

10. Nishiyama T, Terunuma M, Sasaki K, Hanyu S. Right paranephric abscess as a rare late complication of laparoscopic cholecystectomy. Int J Urol 1998 Mar; 5(2): 174 - 5.
11. Cubillana PL, Egea LJA, Montiel MR, Gonzalez AP, Pastor GS, Campos RR, et al. Renal vein thrombosis caused by laparoscopic cholecystectomy. Scand J Urol Nephrol 1998 Feb; 32(1): 56 - 7.

12. Kassasseya A, Ziyani F, Rouffet F. Hemobilia after laparoscopic cystectomy. Apropos of a case. Review of the literature. Ann Chirurg 1997; 51(2): 159 - 62.

13. Balsara KP, Dubash C, Shah CR. Pseudoaneurysm of the hepatic artery along with common bile duct injury following laparoscopic cholecystectomy. A report ot two cases. Surg Endosc 1998 Mar; 12(3): 276 - 7

14. Maw A, Puntis MCA. Delayed splenic rupture complicating laparoscopic cholecystectomy-case report and review. Minimally Invasive Therapy 1997; 6: 87 - 91.

15. Liu SY, Leighton T, Davis I, Klein S, Lippmann M, Bongard F. Prospective analysis of cardiopulmonary responses to laparoscopic cholecystectomy. J Laparoendosc Surg 1991; $1: 241-6$.

16. Wittgen CM, Andrus CH, Fitzgerald SD, Baudendistel LJ, Dahms TE, Kaminski DL. Analysis of the hemodynamic and ventilatory effects of laparoscopic cholecystectomy. Arch Surg $1991 ; 126: 997$ - 1001 .

17. Fitzgerald SD, Andrus CH, Baudendistel LJ, Dahms TE, Kaminski DL. Hypercarbia during carbon dioxide pneumoperitoneum. Am J Surg 1992; 163 : 186 - 90. 